\title{
Maize Production Viability-A Study of Economics, Constraints and Policy Implications for Eastern Uttar Pradesh, India
}

\author{
Jang Bahadur Rana*, J.P. Singh, Shiv Kumar and Vijay Kumar Shahni \\ Department of Agricultural Economics Narendra Deva University of Agriculture \& \\ Technology Kumarganj, Faizabad (U.P.) 224229, India \\ *Corresponding author
}

\section{A B S T R A C T}

Keywords

Gross and net

income, Farm size,

Economics

Article Info

Accepted:

20 May 2018

Available Online:

10 June 2018

In the light of economics evaluation of maize production, primary data for the year 2013-14 were collected from randomly selected 100 farmers of maize growers in Azamgarh district of Uttar Pradesh. In order to coping the objectives of the study, revealed overall average size of farms i.e. 1.05 ha, cropping intensity ranged 197.84 - 236.94 per cent among sample forms. The cost of cultivation of maize per hectare came to Rs. 37387.13. On an average the major components on which maximum cost was incurred being 19.28 per cent whereas minimum in plant protection 1.25 per cent, the cost of production was observed i.e. $1457.97 \mathrm{Rs} / \mathrm{ha}$ whereas productivity witnessed i.e. $31.97 \mathrm{qt} / \mathrm{ha}$. Gross returns was calculated as Rs. 43062.50, cost C1, C2 and C3 was found maximums in large farms Rs. 37003.98, Rs. 24143.98 and Rs. 20281.83, however minimums was observed in marginal farm being Rs. 18152.91, Rs. 6152.91 and Rs. 2848.67, respectively. Input-output ratio was found highest in large farms 1:1.48 and lowest marginal farms 1:1.08.

\section{Introduction}

Maize is one of the most versatile emerging crops having wider adaptability under varied agro-climatic conditions. Globally, maize is known as queen of cereals because it has the highest genetic yield potential among the cereals. It is cultivated on nearly $150 \mathrm{~m}$ ha in about 160 countries having wider diversity of soil, climate, biodiversity and management practices that contributes $36 \%(782 \mathrm{~m} \mathrm{t})$ in the global grain production. The United States of America (USA) is the largest producer of maize contributes nearly $35 \%$ of the total production in the world and maize is the driver of the US economy. The USA has the highest productivity (> $9.6 \mathrm{t} \mathrm{ha-}^{1}$ ) which is double than the global average (4.92 $\left.\mathrm{t} \mathrm{ha}^{-1}\right)$ whereas; the average productivity in India is $2.51 \mathrm{t} \mathrm{ha}^{1}$, maize is the third most important food crops after rice and wheat. According to advance estimate it is cultivated in $8.69 \mathrm{~m}$ ha (2015-16) mainly during Kharif season which covers $80 \%$ area. Maize in India, contributes nearly 9 $\%$ in the national food basket and more than Rs.100 billion to the agricultural GDP at current prices apart from the generating employment to over 100 million man-days at the farm and downstream agricultural and industrial sectors. 
Maize is grown throughout the year in India, but mainly as kharif crop with 85 per cent of the area under cultivation in the season. Maize is globally a top ranking cereal not only in productivity but also as human food, animal feed and as a source of large number of industrial products. The potential for enhanced use of maize for specially purposes based on existing uses and new products to meet the needs a future generation provides the researchers with unique challenges. Major proportion $(55 \%)$ of maize is consumed as food and additional use of maize include as feed, forage and in processing industry. In India 55 per cent of the grain produce concurrently is used for food purposes, about 14 per cent for livestock feed. 18 per cent for poultry feed, 12 per cent for starch and 1 per cent for seed, by the end of this century the expected demand will be around 46 per cent for food, 14 per cent for livestock feed, 19 per cent for poultry feed, 19 per cent for starch industry and 15 per cent for seed.

India contributes merely about 2.5 per cent in world maize production. Karnataka, Bihar, Telangana, Maharashtra, Madhya Pradesh, Tamil Nadu, Andhra Pradesh, Rajasthan and Uttar Pradesh are the major maize producing states; together contribute 60 per cent of area and 70 per cent of maize production in India. Maize is equally important as other cereals take paddy and wheat in the state U.P. as well as in district Azamgarh too.

It covers a considerable area of 703090 hectares under kharif maize, 6050 ha. rabi maize and 48215 ha. zaid maize in the state and production of 1274286 m.t. kharif maize, 13921 m.t. rabi maize and 89784 m. t. zaid maize alongwith the productivity of 36.58 q/ha, 28.05 q/ha and 18.97 q/ha., respectively. (U. P. K. K. A., 2014-15).

In Azamgarh district area under maize stood 37436 hectare with production of $84474 \mathrm{~m}$. t. and productivity $18.53 \mathrm{q} / \mathrm{ha}$ during $2013-2014$ (A. E. S. P. Azamgarh, 2014-15). Maize recognizes as staple food for human being and quality feed for animals, maize serves as a basic raw material as an ingredient to thousands of industrial products that includes starch, oil, protein, alcoholic beverages, food sweeteners, pharmaceutical, cosmetic, film, textile, gum, package and paper industries etc. Keeping in view of aforesaid fact's, the present study was undertaken with the following objectives:

1. To study status household, cropping intensity and us economies, constraint to overcome and to sagest in suitable policy implications thereof.

2. To workout costs and returns and examine resource use efficiency of maize on sample farms.

\section{Materials and Methods}

Purposive-cum random sampling design was used for the selection of district, block, villages and farmers. Azamgarh district of Uttar Pradesh was selected purposively in order to avoid operational inconvenience. Out of 22 blocks of selected district, one block namely Phulpur having highest area under Kharif maize cultivation was selected purposively for the study.

A list of all the villages of selected block was prepared separately alongwith their area under maize cultivation. Five villages from this block were selected randomly. A separate list of maize growers of selected villages was prepared alongwith their size of holdings and further it was grouped into four categories i.e. (1) Marginal: below 1 ha. (2) Small: 1 to 2 ha. (3) Medium: 2 to 4 ha. (4) Large: above 4.0 ha. From this list a sample of hundred growers was selected randomly in proportion to their number of universe in each size group. 


\section{Period of study}

The data was pertained for the agriculture year 2013-14.

\section{Tabular analysis}

Tabular analysis was used to compare the different parameters among marginal, small, medium and large size groups of the farmers. In this computation weighted average were used.

$$
\begin{aligned}
& \text { W.A. }=\frac{\sum \mathbf{W}_{\mathbf{i}} \mathbf{X}_{\mathbf{i}}}{\sum \mathbf{W}_{\mathbf{i}}} \\
& \text { Where, } \\
& \text { W. A. }=\text { Weighted average } \\
& \text { Xi }=\text { Variable } \\
& \mathrm{W}_{\mathrm{i}}=\text { Weight of variable }
\end{aligned}
$$

\section{Cropping intensity}

Cropping intensity is the ratio of total cropped area to net cropped area and was presented in percentage.

Cropping intensity $=$

Total cropped area

\begin{tabular}{c} 
Net cultivated area \\
\hline 100
\end{tabular}

\section{Results and Discussion}

\section{Average size of holding}

The size of holding is supposed to positively correlate with volume of food grains production. The farmers having larger size of holding are economic better off and they are in a position to adopt easily the improved farm practices. On the other hand, the farmer having smaller farm unit have been desired to produce as much they can with a view to marketing both their ends meet and also to improve their economic condition shown as Table 1.
This table indicates that overall average size of farms was found to be 1.05 ha, which varied from 0.49 ha. on marginal, 1.32 ha. on small , 2.41 ha. on medium and 4.16 ha. On large farms along with total cultivated area 105.09 ha. on sample farms. It is interestingly been that operational percentage of cultivation area decrease with increase size of forms excludes main cal say of farm.

\section{Cropping intensity}

Cropping intensity is an index of intensity of land use determined by the numbers of crop grown in a particular area (field) during a year of cropping intensity exhibited maximum was (236.94 per cent) on marginal followed by small (235.98 per cent), medium (223.03 per cent) and large (197.84 per cent) with an overall average i.e. 224.86 per cen.

\section{Economics of maize cultivation}

Costs and returns of maize on sample farms have been worked out and presented in this section. The cost of cultivation per hectare has been worked out. The different cost concepts were used for maize production. Per hectare output was estimated and valued as gross income, net income, and family labour income. Thus, measures of farm profits were represented as farm business income.

\section{Inputs}

For inputs estimates, the various factors which enters into cost have been considered such as human labour (both family and hired), bullock labour, machinery charges, seed, manures and fertilizer, irrigation, plant protection, interest on working capital, rental value of land, interest on fixed capital and $10 \%$ covered managerial cost against $\mathrm{C}_{2}$.

\section{Cost cultivation of maize}

Per hectare costs on various input factors in 
maize production were worked out. The details of input costs are shown in Table 2 indicate that on an average, the cost of cultivation of maize per hectare came to Rs. 37387.13. The cost of cultivation was maximum on large farms (Rs. 42483.62) followed by medium farms (Rs. 40217.13), small farms (Rs. 37887.43) and marginal farms (36346.63) respectively.

Per hectare cost of cultivation was highest (Rs. 42483.62) on large farms, mainly due to maximum investment on fixed capital compared to the small and marginal farms. On an average the study further reveals that major components on which maximum cost was incurred being 19.28 per cent on human labour followed by manures and fertilizer 10.69 per, machinery charges 8.25 per cent, seed 4.88 per cent, irrigation 3.68 per cent, plant protection 1.25 per cent and bullock labour 0.69 per cent. A similar trend indicated on all categories of sample farms.

The cost incurred on interest on working capital, rental value of owned land, interest on fixed capital and $10 \%$ managerial cost of subtotal was calculated as $0.69,32.61,8.96$ and 9.09 per cent of total costs, respectively.

The maximum share among these costs was rental value of owned land being 32.61 per cent of total cost per hectare.

\section{Structure of cost}

On the sample farms the figure of costs and returns has been summarized in this part beside the estimates of total cost. The cost was worked out on the basis of three cost concept i.e. cost $\mathrm{A}_{1}$, cost $\mathrm{B}_{1}$ and $\mathrm{B}_{2}, \operatorname{cost} \mathrm{C}_{1}, \mathrm{C}_{2}$ and $\mathrm{C}_{3}$.

Similarly, the various measures of farm profits such as family labours, net returns over cost $\mathrm{C}_{1}, \mathrm{C}_{2}$ and $\mathrm{C}_{3}$, farm business income, farms investment income, cost of production per quintal at $\operatorname{cost} \mathrm{C}_{1}, \mathrm{C}_{2}$ and $\mathrm{C}_{3}$ input-output ratio on cost $A_{1}$, cost $B_{1}, B_{2}$, cost $C_{1} C_{2}$ and $C_{3}$, production and productivity for maize crop have been worked out.

Table.1 Average size of holding on different size-group of sample farm

\begin{tabular}{|c|c|c|c|c|}
\hline S. No. & $\begin{array}{l}\text { Size of } \\
\text { farm }\end{array}$ & Number of farms & $\begin{array}{l}\text { Total cultivated } \\
\text { area (ha) }\end{array}$ & A verage size of farm (ha) \\
\hline 1 & Marginal & 67 & $\begin{array}{c}32.50 \\
(30.23)\end{array}$ & 0.49 \\
\hline 2 & Small & 16 & $\begin{array}{c}21.14 \\
(20.12)\end{array}$ & 1.32 \\
\hline 3 & Medium & 11 & $\begin{array}{c}26.47 \\
(25.19)\end{array}$ & 2.41 \\
\hline 4 & Large & 6 & $\begin{array}{c}24.98 \\
(23.77)\end{array}$ & 4.16 \\
\hline \multicolumn{2}{|c|}{ Total } & 100 & $\begin{array}{c}105.09 \\
(100)\end{array}$ & 1.05 \\
\hline
\end{tabular}

Note- Figures in parentheses show the per cent to corresponding total 
Table.2 Per hectare costs of cultivation of maize on sample farms

\begin{tabular}{|c|c|c|c|c|c|c|}
\hline \multirow[t]{2}{*}{ S.N. } & \multirow[t]{2}{*}{ Particulars } & \multicolumn{4}{|c|}{ Size group of sample farms } & \multirow[t]{2}{*}{ Overall average } \\
\hline & & Marginal & Small & Medium & Large & \\
\hline \multirow[t]{2}{*}{1} & \multirow[t]{2}{*}{ Human labour } & 6962.25 & 7341.49 & 7878.17 & 8376.98 & 7208.56 \\
\hline & & (19.16) & $(19.38)$ & $(19.59)$ & $(19.72)$ & $(19.28)$ \\
\hline \multirow[t]{2}{*}{ a } & \multirow[t]{2}{*}{ Family Labours } & 5594.52 & 5143.63 & 3538.59 & 2979.40 & 5139.32 \\
\hline & & $(15.39)$ & $(13.58)$ & $(8.80)$ & $(7.01)$ & $(13.75)$ \\
\hline \multirow[t]{2}{*}{ b } & \multirow[t]{2}{*}{ Hired Labours } & 1367.73 & 2197.85 & 4339.58 & 5397.58 & 2069.24 \\
\hline & & $(3.76)$ & $(5.80)$ & $(10.79)$ & $(12.71)$ & $(5.53)$ \\
\hline \multirow[t]{2}{*}{2} & \multirow{2}{*}{ Bullock labour } & 281.00 & 275.00 & 154.00 & 115.00 & 256.11 \\
\hline & & $(0.77)$ & $(0.73)$ & $(0.38)$ & $(0.27)$ & $(0.69)$ \\
\hline \multirow[t]{2}{*}{3} & \multirow[t]{2}{*}{ Machinery charges } & 2964.50 & 3250.80 & 3314.18 & 3577.00 & 3085.52 \\
\hline & & $(8.16)$ & $(8.58)$ & $(8.24)$ & $(8.42)$ & $(8.25)$ \\
\hline \multirow[t]{2}{*}{4} & \multirow[t]{2}{*}{ Seed cost } & 1846.01 & 1727.70 & 1826.31 & 1830.58 & 1823.99 \\
\hline & & $(5.08)$ & $(4.56)$ & $(4.54)$ & $(4.31)$ & $(4.88)$ \\
\hline \multirow[t]{2}{*}{5} & \multirow[t]{2}{*}{ Manure \& fertilizer } & 3679.49 & 4170.12 & 4752.16 & 5699.80 & 3997.20 \\
\hline & & $(10.12)$ & $(11.01)$ & $(11.82)$ & $(13.42)$ & $(10.69)$ \\
\hline \multirow[t]{2}{*}{6} & \multirow[t]{2}{*}{ Irrigation charges } & 1427.79 & 1148.60 & 1389.85 & 1354.44 & 1374.54 \\
\hline & & (3.93) & $(3.03)$ & $(3.46)$ & $(3.19)$ & $(3.68)$ \\
\hline \multirow[t]{2}{*}{7} & \multirow[t]{2}{*}{ Plant Protection } & 448.79 & 476.86 & 516.64 & 559.58 & 467.39 \\
\hline & & $(1.23)$ & $(1.26)$ & $(1.28)$ & $(1.32)$ & $(1.25)$ \\
\hline \multirow{2}{*}{\multicolumn{2}{|c|}{ Total working capital }} & 17609.83 & 18390.57 & 19831.32 & 21513.37 & 18213.32 \\
\hline & & $(48.45)$ & $(48.54)$ & $(49.31)$ & $(50.64)$ & $(48.72)$ \\
\hline \multirow[t]{2}{*}{8} & \multirow[t]{2}{*}{ Interest on working capital } & 211.32 & 263.86 & 298.15 & 308.36 & 235.10 \\
\hline & & $(0.58)$ & $(0.70)$ & $(0.74)$ & $(0.73)$ & $(0.63)$ \\
\hline \multirow[t]{2}{*}{9} & \multirow[t]{2}{*}{ Rental value on owned land } & 12000.00 & 12350.00 & 12750.00 & 12860.00 & 12190.10 \\
\hline & & $(33.02)$ & $(32.60)$ & $(31.70)$ & $(30.27)$ & $(32.61)$ \\
\hline \multirow[t]{2}{*}{10} & \multirow[t]{2}{*}{ Interest on owned fixed capital } & 3221.24 & 3438.69 & 3681.56 & 3939.74 & 3349.78 \\
\hline & & $(8.86)$ & $(9.08)$ & $(9.15)$ & $(9.27)$ & $(8.96)$ \\
\hline & Sub Total & 33042.39 & 34443.12 & 36561.03 & 38621.47 & 33988.30 \\
\hline & & $(90.91)$ & $(90.91)$ & $(90.91)$ & $(90.91)$ & $(90.91)$ \\
\hline 11 & $10 \%$ cost on managerial cost of sub total & 3304.24 & 3444.31 & 3656.10 & 3862.15 & 3398.83 \\
\hline & & $(9.09)$ & $(9.09)$ & $(9.09)$ & $(9.09)$ & $(9.09)$ \\
\hline & Grand Total & 36346.63 & 37887.43 & 40217.13 & 42483.62 & 37387.13 \\
\hline & & $(100.00)$ & $(100.00)$ & $(100.00)$ & $(100.00)$ & $(100.00)$ \\
\hline
\end{tabular}


Table.3 Per hectare costs and returns of maize in on sample farms

(Rs. /ha)

\begin{tabular}{|c|c|c|c|c|c|c|}
\hline \multirow[t]{2}{*}{ S.N. } & \multirow[t]{2}{*}{ Item Costs } & \multicolumn{5}{|c|}{ Size group of farms } \\
\hline & & Marginal & Small & Medium & Large & Overall average \\
\hline 1 & Cost $A_{1}$ & 12226.63 & 13510.79 & 16590.88 & 18842.33 & 13309.10 \\
\hline 2 & Cost $\mathrm{B}_{1}$ & 15447.87 & 16949.48 & 20272.44 & 22782.07 & 16658.88 \\
\hline 3 & Cost $\mathrm{B}_{2}$ & 27447.87 & 29299.48 & 33022.44 & 35642.07 & 28848.98 \\
\hline 4 & Cost $C_{1}$ & 21042.39 & 22093.12 & 23811.03 & 25761.47 & 21798.20 \\
\hline 5 & Cost $C_{2}$ & 33042.39 & 34443.12 & 36561.03 & 38621.47 & 33988.30 \\
\hline 6 & Cost $C_{3}$ & 36346.63 & 37887.43 & 40217.13 & 42483.62 & 37387.13 \\
\hline 7 & \multicolumn{6}{|l|}{ Yield (qt./ha ) } \\
\hline $\mathbf{A}$ & Main Product(qt./ha) & 31.45 & 33.13 & 32.24 & 34.21 & 31.97 \\
\hline B & By-Product (qt./ha) & 40.32 & 43.25 & 42.67 & 41.33 & 41.11 \\
\hline 8 & Gross income & 39195.30 & 44008.44 & 54494.30 & 62765.45 & 43062.50 \\
\hline $\mathbf{A}$ & Main Product(Rs./ha) & 33542.75 & 33853.23 & 40683.76 & 45671.87 & 35105.69 \\
\hline $\mathbf{B}$ & By-Product (Rs./ha) & 5652.55 & 10155.21 & 13810.54 & 17093.58 & 7956.82 \\
\hline 9 & Net return over cost $C_{1}$ & 18152.91 & 21915.32 & 30683.27 & 37003.98 & 21264.30 \\
\hline 10 & Net return over cost $C_{2}$ & 6152.91 & 9565.32 & 17933.27 & 24143.98 & 9074.20 \\
\hline 11 & Net income & 2848.67 & 6121.01 & 14277.17 & 20281.83 & 5675.37 \\
\hline 12 & Family labour income & 11747.43 & 14708.96 & 21471.86 & 27123.38 & 14213.52 \\
\hline 13 & Farm business income & 26968.67 & 30497.65 & 37903.42 & 43923.12 & 29753.40 \\
\hline 14 & Farm investment income & 21374.15 & 25354.01 & 34364.83 & 40943.72 & 24614.08 \\
\hline 15 & Cost of production (Rs. / qt.) & 1323.55 & 1592.35 & 1795.76 & 1981.30 & 1457.97 \\
\hline $\mathbf{A}$ & Cost $\mathrm{C}_{1}$ & 1156.79 & 1434.62 & 1616.85 & 1783.09 & 1289.43 \\
\hline B & Cost $\mathrm{C}_{2}$ & 166.76 & 157.73 & 178.91 & 198.21 & 168.54 \\
\hline 16 & \multicolumn{6}{|l|}{ Input - Output ratio } \\
\hline $\mathbf{I}$ & $\mathrm{A}_{1}$ basis & $1: 3.21$ & $1: 3.26$ & $1: 3.28$ & $1: 3.33$ & $1: 3.24$ \\
\hline II & $\mathrm{B}_{1}$ basis & $1: 2.54$ & $1: 2.60$ & $1: 2.69$ & $1: 2.76$ & $1: 2.58$ \\
\hline III & $\mathrm{B}_{2}$ basis & $1: 1.43$ & $1: 1.50$ & $1: 1.65$ & $1: 1.76$ & $1: 1.49$ \\
\hline IV & $\mathrm{C}_{1}$ basis & $1: 1.86$ & $1: 1.99$ & $1: 2.29$ & $1: 2.44$ & $1: 1.98$ \\
\hline $\mathbf{V}$ & $\mathrm{C}_{2}$ basis & $1: 1.19$ & $1: 1.28$ & $1: 1.49$ & $1: 1.63$ & $1: 1.27$ \\
\hline VI & $\mathrm{C}_{3}$ basis & $1: 1.08$ & $1: 1.16$ & $1: 1.36$ & $1: 1.48$ & $1: 1.15$ \\
\hline
\end{tabular}

Note- Figure in parentheses shows the percent to corresponding total. 


\section{Measures of cost and income of maize}

Costs and return of maize production per hectare is given in Table 3 the table shows the cost of production and return on marginal small medium and large farms of Phulpur block. Main product of maize yield was calculated as $31.45,33.13,32.24$ and 34.21 quintal and average yield 31.97 quintal per hectare. Gross returns was calculated as maximum in large farms Rs. 62765.45 followed by medium farms Rs. 54494.30, small farms Rs. 44008.44, marginal farms 39195.30 and observed gross return Rs. 43062.50, net income per hectare over cost $C_{3}$ was found highest in large farms Rs. 20281.83 and lowest marginal farm Rs. 2848.67 medium farms Rs. 6121.01, and small farms 14277.17 net return over cost $C_{1}$ large farms is Rs. 37003.98, followed by, medium farms 30683.27 small farms Rs. 21915.32, and marginal farms Rs. 18152.91, respectively and net return over cost $\mathrm{C}_{2}$ is highest in large farms Rs. 24143.98 followed by medium farms Rs. 17933.27 small farms Rs. 9565.32, and marginal farms Rs. 6152.91, respectively.

The input-output ratio was found highest in large farms 1:1.48 followed by medium farms 1:1.36 small farms 1:1.16, and marginal farms $1: 1.08$, respectively.

\section{Income from maize production}

Incomes from maize production were calculated and given in Table 3 Per hectare gross income was observed maximum under large farms i.e. Rs. 62765.45 followed by medium farms (Rs. 54494.30) small farms (Rs 44008.44), and marginal farms (Rs 39195.30), respectively. Per hectare average gross income came to Rs. 43062.50 where as net income was Rs. 5675.37 overall average, farm business income, family labour income and farm investment income were worked out to be Rs. 29753.40 , Rs. 14213.52 and Rs. 24614.08, respectively. Cost of production per quintal of maize was computed to be Rs. 1981.30, Rs. 1795.76, Rs. 1592.35 and 1323.55 on large, medium, small and marginal farms, respectively with an average of Rs. 1457.97. Average input-output ratio on $\operatorname{cost} A_{1}$, cost $B_{1}$, cost $B_{2}$, cost $C_{1}$, cost $C_{2}$ and cost $C_{3}$ were worked out and came to $1: 3.24$, $1: 2.58,1: 1.49,1: 1.98,1: 1.27$ and 1:1.15, respectively. Input-output ratio related to cost $\mathrm{C}_{3}$ was highest on large farms (1:1.48) followed by medium farms (1:1.36), small farms (1:1.16) and marginal farms 1:1.08. In respect of cost $\mathrm{C}_{2}$ input-output ratio (1:1.63) was highest on large farms followed by medium farms (1:1.49), small farms (1:1.28) and marginal farms (1:1.19). Cost $C_{1}$ inputoutput ratio (1:2.44) was highest large farms followed by medium farms (1:2.29), small farms (1:1.99) and marginal farms (1:1.86). In respect to input-output ratio $(1: 1.76)$ of $B_{2}$ was found highest on large farms followed by medium farms (1:1.65) small farms (1:1.50) and marginal farms (1:1.43) whereas, in Cost $\mathrm{B}_{1}$ the input-output ratio was highest on large farms $(1: 2.58)$ followed by medium farms (1:2.76) small farms (1:2.60) and marginal farms(1:2.54). In reference to cost $A_{1}$, Inputoutput ratio cost $A_{1}$, was highest on large farms (1:3.33) followed by medium farms (1:3.28), small farms (1:3.26) and marginal farms (1:3.21), respectively.

\section{Suggestive policy implications to overcome} the production constraints of maize

1. (i) State Agriculture Department should ensure the timely and adequate supply of inputs viz., fertilizer, HYV seed, pesticides so that farmers can apply recommended inputs for increasing the production. (ii) Ensure the adequate farmers training on maize production technology for increasing the knowledge level of farmers. 
2 (i) It is to be ensured that Kisan Credit Card and other banking facilities should be available at affordable and easy process. Crop loan at proper time with easy process should be provided and financial support should be given on lowest interest by the financial agencies. (ii) Subsidy should also be provided to encourage the establishment of rural maize processing units.

3 (i) Electric supply and communication facilities should be assured so as to encourage the smooth functioning of maize electric tubewell. (ii) The irrigation department should provide the irrigation water properly and timely through canal due to which production may increase and cost of cultivation may be reduced.

4 Transportation facilities should be improved by Government for easy conveyance to the produce and raw material from one territory to another territory.

\section{References}

Alejo, S. Carvajal, and Saavedra, A. L. (2001 Artisanal agricultural food production in the south of Guanajuato and the role of professionals in food production and marketing. (Diagnosticoy alternativas de desarrollo agro industrial) Revista
Chapingo. Agropecuaria; 4(2):63-65.

SerieIngenieria

Badmus M.A. and O.S. Ariyo (2011) Forecasting Cultivated Areas and Production of Maize in Nigerian using Arima Model. Asian Journal of Agricultural Sciences; 3 (3): 171-176.

Faruq Hasan M. (2008) "Economic Efficiency and Constraints of Maize Production in the Northern Region of Bangladesh." $J$. Innov. Dev. Strategy; 1(1):18-32.

Murthy, C.; Vilas Kulkarni and Kerur, B. P. (2015) "Cost and return structure of maize production in North Karnataka." $C A B$ International Research Journal of Agricultural Economics and Statistics; 6 (2):364-370.

Navadkar, D.S. Amale, A.J. Gulave, C.M. and Nannaware, V.M. (2012) economics of production and marketing of kharif maize in Ahmednagar district of Mahrastra State. Agriculture Situation in India; 69 (6):309 - 316.

Paudel, p., and A. Matsuoka (2009) "Cost efficiency estimates of maize production in Chitwan district Nepal. Journal of Agricultural Economics;" 55(3):139-148.

Verma, A. R. (2007) Economics of production, resource use efficiency, marketing and constraints of maize in tribal district Dhar of Madhya Pradesh. Agricultural Marketing; 46 (4):13-22.

\section{How to cite this article:}

Jang Bahadur Rana, J.P. Singh, Shiv Kumar and Vijay Kumar Shahni. 2018. Maize Production Viability-A Study of Economics, Constraints and Policy Implications for Eastern Uttar Pradesh, India. Int.J.Curr.Microbiol.App.Sci. 7(06): 2776-2783. doi: https://doi.org/10.20546/ijcmas.2018.706.326 